\title{
Industri Budaya dalam Menciptakan Standar Kehidupan Perempuan : Kajian Perkembangan Media
}

\author{
Maisaroh $_{1}$ \\ ${ }_{1}$ Program Studi Ilmu Komunikasi Fakultas Ilmu Komunikasi \\ Universitas Padjadjaran \\ ımaisarohbatubara24@gmail.com
}

\begin{abstract}
ABSTRAK
Media merupakan salah satu kanal dalam mentransmisikan nilai-nilai budaya berikut perkembangannya. Salah satu hal yang digaungkan media bersamaan dengan perkembangan ini ialah melalui industri budaya. Industri budaya berbicara bagaimana para petinggi media menciptakan pasar dengan standardisasi, masifikasi, dan komodifikasi tertentu. Hal ini bukan menjadi ekspresi dari budaya yang hidup di masyarakat, melainkan hanya sebagai produk dari industri semata. Pembahasan industri budaya tidak pernah terlepas dari bagaimana kehidupan perempuan sebagai salah satu pihak yang menjadi target pasar dari industri budaya, sebab perbincangan tentang perempuan akan selalu menarik banyak pihak dari berbagai sudut pandang dalam melihat fenomenanya. Ini merupakan konsekuensi logis dari media yang hidup dalam sistem kapitalisme: memaksimalkan keuntungan, meminimalkan biaya pengeluaran. Tiga konsep utama dalam industri budaya ini -standardisasi, masifikasi, dan komodifikasi- membangunkan kesadaran palsu perempuan untuk hidup sesuai dengan selera media. Perkembangan teknologi informasi dan komunikasi menjadi momentum tersendiri bagi para petinggi media menciptakan pasar ini. Hematnya, perkembangan teknologi dalam era digitalisasi ini justru menjadi jalan pintas dalam menyebarluaskan standar-standar tersebut. Perkembangan teknologi ini besifat suportif terhadap optimalisasi komunikasi industri budaya dalam menciptakan dunia dengan standar tertentu. Tujuan dari tulisan ini adalah mencari spesifikasi konten media seperti apa yang menggambarkan bagaimana perempuan dan laki-laki dan mencari tahu bagaimana hard content dan soft content digambarkan. Sehingga tulisan deskripsi ilmiah ini dapat menjadi acuan standar refleksi bagi individu dalam menginternalisasi dan memahami pesan-pesan yang terkandung di dalam media agar individu dapat lebih kritis dalam melihat konten media yang ada. Melalui tulisan ini pula, seharusnya praktisi media mulai menyadari bahwa semestinya diciptakan kategori baru yang seyogyanya menggambarkan perempuan dan laki-laki pada konten yang lebih umum. Metode yang digunakan peneliti adalah metode analisis konten didukung dengan studi literatur dan dokumen terkait. Penulis mengumpulkan 30 artikel dari media berita online, hasil dari kajian penelitian menunjukkan, hard content yang berat membahas bisnis, olahraga, kejahatan, dan pengetahuan/teknologi cenderung disematkan kepada laki-laki. Soft content yang berat membahas tentang dunia fashion, kecantikan, edukasi, keuangan pribadi, makanan dan perjalanan, kesenian, serta hiburan, biasanya lebih disematkan kepada kehidupan perempuan oleh media.
\end{abstract}

Kata kunci : konten media, representasi perempuan, hard konten dan soft konten. 


\begin{abstract}
Media is a part of channels that transmitted culture values and its development. One of the things that they brought is through cultural industry. Cultural industry included how the stakeholders create the market with standardization, massification, and commodification. This culture is not a result of expression of society but stakeholders do create them. This topic, too, always attached to the existence of women, where they one of the prey of this cultural industry, which always been intriguing. This is what we call as logical consequences where media lives in capitalism era. Three main concepts of cultural industry arose women false consciousness to live within media's standard. The purpose of this writing is to seek for how media content represent men and women in their certain way followed by how hard and soft content being written. So that this research could be a reference to those people internalizing and understanding thoroughly messages written by media. Through this research, researcher hopes that media practitioners could create new terms (besides hard and soft content) to make the specification seems fairer. Researcher used analysis content followed by the text and documents supported. Researcher colledted 30 articles from three online news media. The result suggested that hard content of media tended to talk about business, sport, crimes, and technology attached to men. On the other hand, soft content tended to talk about fashion, beauty, personal finance, foods and travelling, art, and entertainment attached to women by media.
\end{abstract}

Keywords : media content, representation of women, hard content and soft content

\title{
Pendahuluan
}

Kajian perihal perempuan memang selalu menggelitik para peneliti dan masyarakat untuk turut mendiskusikan tentang perempuan. Konstruksi bagaimana perempuan digambarkan, akan paling dekat dengan masyarakat melalui media, di mana salah satu fungsi dari media itu sendiri adalah mentransmisikan nilai-nilai budaya kepada masyarakat. Bagaimana perempuan digambarkan dalam media, beberapa dekade ini menimbulkan banyak pertanyaan, kegelisahan, bahkan berujung pada penuntutan kesetaraan status dan peran dengan laki-laki. Kemudian hal ini lah yang menimbulkan pada isu kesetaraan gender dan menjadi salah satu dari 17 komponen Sustainable Development Goals alias SDGs.

Meskipun frekuensi kemunculan perempuan tetap eksis dalam konten pada media secara porsi yang tidak kurang dari laki-laki, tetapi peran mereka tetap didominasi menjadi pihak kedua terhadap laki-laki. Pernyataan ini diperkuat dengan fakta kecil yang implisit. Film-film yang terdapat dalam golongan Blockbuster seperti Avengers atau Star Wars masih memperlihatkan skala kecil di mana perempuan menjadi pahlawan utama dalam film-film yang mereka produksi. Pemeran pahlawan, karena produksi yang tinggi diperankan oleh lakilaki, menjadi erat kaitannya dengan kepercayaan bahwa pahlawan adalah mereka yang lakilaki. Padahal, terdapat juga perempuan-perempuan yang memerankan tokoh pahlawan yang kemudian menjadi dambaan masyarakat seperti Wonder Women, Black Widow, ataupun Captain Marvel.

Tidak hanya pada konten media, perempuan juga turut terpinggirkan pada faktor redaksi konten berita. Aturan obrolan panggung pada berita antara laki-laki dan perempuan pun akan menciptakan suasana yang berbeda. Laki-laki akan digambarkan dengan suasana yang independen dan nampak maskulin. Sedang perempuan sering kali digambarkan dalam ranah yang penuh pembahasan yang bersifat personal atau dalam setting yang berhubungan dengan kekeluargaan. 
Pembawaan dalam pemberitaan (jurnalis) perempuan pun biasa ditempatkan pada okupasi ringan seperti program anak-anak dan perempuan. Sedangkan laki-laki ditempatkan pada isu berita nasional, politik, dan ekonomi misalnya. Kurangnya jumlah keterlibatan perempuan dalam produksi konten berita, diasumsikan mengantar pada kurangnya keterwakilan perempuan dalam konten berita. Surat kabar dengan persentase editor perempuan yang tinggi tampaknya tidak membedakan antara reporter pria dan perempuan ketika menugaskan pemberitaan, seperti yang terjadi di ruang redaksi yang didominasi pria. Pria-pria yang bekerja dengan bos perempuan akan lebih menerima kerja yang diberikan agar dapat terlihat baik depan bos mereka.

Dalam pembagian tugas para redaksi :

1. Manajerial Pria: perempuan ditugaskan untuk berita sektor bisnis dan pendidikan, sedangkan pria ditugaskan untuk berita politik.

2. Makalah dengan editor yang didominasi pria berisi berita dengan fokus yang lebih negatif. Karena dengan nilai tradisional "ketika berita berdarah, itu yang menjadi terdepan" yang masih dipegang oleh mereka. Liputan kriminal menjadi aspek penting dalam berita yang didominasi oleh editor laki-laki (Craft \& Wanta, 2004).

Selain dua kanal tersebut dalam menggambarkan perempuan, kanal lain pada media yaitu iklan. Iklan menjadi tempat di mana suatu hal dipromosikan dan disampaikan pesanpesan kebaikan yang terkandung di dalamnya. Namun, pencitraan perempuan pada iklan pun juga mengalami keterpinggiran sama seperti kanal-kanal yang sudah disebut sebelumnya. Kecantikan perempuan kerap kali menjadi daya tarik sebuah iklan agar banyak dibeli oleh target konsumennya. Sebagai contoh, iklan pompa air Shimizu dan Softener Soklin, yang jelas sekali menjadikan perempuan sebagai objek promosi iklan tersebut. Keduanya samasama menyoroti hal yang sensual yang terdapat pada tubuh wanita. Meskipun bukan itu yang menjadi inti dari iklannya, namun jelas, sorotan sensual tersebut menjadi nilai emas bagi iklan itu sendiri. Sehingga iklan tersebut pun mendapat ban dari KPI untuk kembali ditayangkan pada televisi.

Selain itu, iklan Axe dengan slogannya 'bikin bidadari lupa diri', terdapat seorang lelaki yang menyemprotkan parfum ke badannya, kemudian para perempuan yang diilustrasikan sebagai bidadari tiba-tiba jatuh dari langit dan mendekati lelaki tersebut. Terlihat bahwa di sini perempuan menjadi sebuah objek sebagai akibat dari sisi maskulinitas laki-laki setelah ditonjolkan. Perempuan bisa 'dibeli' hanya dengan setelah melihat maskulinitas dari seorang lelaki.

Perempuan masa kini hidup di zaman yang semakin modern. Media semakin gencar dalam menciptakan industri mereka supaya laku di pasaran. Berbagai jalan pemasaran digencarkan oleh kanal media mulai dari manajerial redaksi berita, iklan, sinetron atau bahkan pada konten berita yang dimuat dalam institusi terlembagakan dalam bentuk portal berita. Istilah pun muncul dalam dunia praktisi media terkait konten berita dimuat yang mengacu pada gender : hard content dan soft content. Kedua istilah ini, juga merupakan sebuah hasil dari adanya nada-nada konten pada teks media terkait cara mereka dalam menggambarkan konten perempuan dan laki-laki. Fenomena ini pun kemudian turut membuka peluang komunikasi bagi para praktisi media dalam menyesuaikan kontennya dengan kebutuhan dan keinginan masyarakat. Konten yang sesuai dengan perkembangan zaman lah yang nantinya akan banyak mendapat perhatian masyarakat atau bersifat 
newsworthy. Sehingga nantinya, ada kelas-kelas tersendiri dalam penulisan berita. Perempuan yang sering disandingkan dengan soft content dan laki-laki dengan hard content nya. Dimulai dari marginalisasi perempuan, hingga pada kategorisasi yang tercipta dalam membingkai berita.

\section{Kajian Pustaka \\ Framing}

Teori framing ini, menjadi teori yang digunakan peneliti pada artikel jurnal. Framing adalah bagaimana media menyoroti aspek dari peristiwa atau masalah dan membuat koneksi di antara mereka untuk menyampaikan interpretasi, solusi, dan/evaluasi tertentu (Perloff, 2014). Berbicara tentang framing, maka kita juga akan terikat dengan dua konsep lainnya yaitu agenda setting dan priming. Konsep-konsep ini juga menyoroti efek kognitif individu yang disebabkan oleh cara media mengemas berita terhadap pandangan mereka terhadap konten media tersebut. Sederhananya, framing akan melihat bagaimana sudut pandang yang digunakan praktisi media dalam menuliskan atau menciptakan konten media yang dibuatnya. Framing bisa dilihat dalam dua pendekatan, episodik dan tematik. Pendekatan episodik akan berfokus pada personal yang sedang dibicarakan dalam media, sedangkan tematik akan berfokus pada sistem/program/kebijakan terkait yang terdapat dalam suatu permasalahan.

Efek framing yang dihasilkan media, tidak selalu bekerja dalam satu komponen yang menetap pada individu. Misalnya saja pemberitaan tentang kejahatan pemerkosaan terhadap perempuan. Penulis berita bisa saja berpihak pada pelaku pemerkosaan dan pembaca mengamininya dengan rasa iba terhadap hukuman yang diberikan kepada tersangka. Namun, bisa saja dalam waktu yang sama di sisi yang berbeda, pembaca berpikir bahwa mau bagaimanapun, hukuman tersebut dirasa sudah setimpal dengan pelaku pemerkosaan. Kita bisa berkaca pada peristiwa yang sedang hangat dibicarakan di Manchester, Reynhard Sinaga. Bagaimana framing media Inggris dengan Indonesia dalam menggambarkannya cukup berbeda. Inggris berfokus pada framing tematik, membahas bagaimana kronologi kejadian serta bagaimana pandangan hokum Inggris terhadap kasus Reynhard. Sedangkan media Indonesia cenderung berfokus pada framing episodik. Media di Indonesia tidak sedikit yang menyinggung bagaimana kehidupan seorang Reyhanrd, atau bagaimana headline berita tentangnya diawali dengan identitas kebangsaan: "WNI". Tentunya hal ini berpengaruh pada bagaimana pembaca merespon framing tersebut.

Menurut Perloff, kekuatan framing akan lebih bekerja pada empat situasi. Pertama, ketika isu yang dibahas merupakan peristiwa terbaru. Kedua, framing tidak akan bekerja pada komunikan yang sudah memiliki pendirian atau prinsip. Ketiga, framing akan bekerja kepada komunikan dengan nilai yang senada yang dibawakan pada konten media tersebut. Keempat, framing akan kurang bekerja, saat seluruh media kurang memberikan framing yang sama terhadap suatu gagasan yang sama.

\section{Hard content vs soft content}

Dua istilah hard dan soft content menjadi istilah yang sudah sangat lazim dalam dunia media, terutama berita. Istilah ini bukan merupakan istilah ilmiah, tetapi merupakan istilah yang dikembangkan oleh para praktisi media dalam menentukan kategori konten berita yang dibuatnya. Meskipun keduanya sudah sangat lazim digunakan dalam praktik media, namun hingga saat ini belum ada standar baku dalam menetapkan batasan dari definisi keduanya. Namun, definisi dan konsep yang belakangan ini berkembang dalam praktik media 
menyebutkan, kategori seperti politik, ekonomi, dan permasalahan sosial termasuk ke dalam kelas hard content. Sedangkan berita terkait bencana, gossip, dan hiburan termasuk ke dalam kelas soft content (Reinemann, Stanyer, \& Scherr, 2011).

Shoemaker dan Cohen memberikan definisi lain terhadap dua kategori tersebut. hard content mengacu pada peristiwa darurat yang memang harus segera disebarluaskan. Jika tidak, maka berita tersebut akan cepat usang termakan oleh peristiwa yang lainnya sehingga aka nada nilai yang hilang dari apa yang dibutuhkan masyarakat. Oleh karenanya, peristiwa yang dilaporkan pada hard content pun merupakan kejadian yang masih fresh untuk disdebarluaskan. Berbeda dengan hard, pemberitaan soft content tidak diburu-buru waktu. Pemberitaannya pun memang tidak terikat waktu sebab kontennya dianggap bukan konten yang genting atau mewakili kepentingan orang banyak.

Patterson juga memberikan definisinya terhadap batasan hard content dan soft content. Hard content ditekankan kepada konten yang melibatkan para pemimpin, permasalahan besar, dan disrupsi signifikan yang berpengaruh terhadap kehidupan seharihari, misalnya bencana gempa bumi. Sedangkan soft content cenderung kepada pemberitaan media yang personal-sentris, tidak terikat waktu, dan tidak menjawab kebutuhan banyak orang.

Dua kategori ini, tidak hanya ditentukan melalui komponen-komponen yang terkandung di dalam teks media tersebut. Namun framing, atau bagaimana konten media dikemas oleh para praktisi media juga turut memberi tendensi kategori konten media tersebut. Pada kesimpulannya, definisi dan batasan dari hard dan soft content bukanlah sebuah karakteristik tunggal yang berfokus hanya pada satu dimensi saja. Bahasan mengenai kategori konten teks media ini, merupakan sebuah perangkat karakteristik yang spesifik dan terkumpul di dalam satu kombinasi dengan payung yang sama. Namun, terdapat gagasan yang mulai berkembang seiring kaum feminis bergerak menuntut kesetaraan gender. Soft content kerap diasosiasikan kepada pemberitaan dengan subjek perempuan di dalamnya. Sehingga peneliti memiliki pertanyaan penelitian,

\section{RQ1 : Mengapa soft content kerap diasosiasikan dengan perempuan dalam teks} media?

\section{Perempuan dan media}

Perempuan memiliki nilai-nilai tertanam tersendiri di mata masyarakat atau dalam bahasa lain, perempuan adalah produk masyarakat. Besar atau kecil, media turut andil dalam menciptakan nilai-nilai mengenai perempuan tersebut. Seperti yang sudah disinggung pada bahasan hard dan soft content, pembagian kedua kategori ini diamini sebagai konsekuensi gender. Laki-laki dengan kecenderungan hard content-nya, sedang perempuan dengan softnya. Framing yang cenderung kuat dan homogen antara institusi satu dengan yang lainnya, turut membangun konstruksi tentang perempuan.

Media tidak jarang menggambarkan perempuan pada posisi yang tidak sekuat lakilaki. Kita bisa dengan mudah melihat bagaimana sinetron di Indonesia menggambarkan perempuan; sensasi, drama, penderitaan, hingga ratu kecantikan. Pada film-film yang terdapat di salah satu stasiun TV swasta Indonesia, perempuan kerap kali digambarkan melalui penderitaannya dalam rumah tangga. Bagaimana mereka dikhianati suaminya yang bermain curang dengan perempuan lain, sehingga lama-kelamaan muncul term 'pelakor' atau perebut lelaki orang.

Selain sinetron, dalam dunia Instagram, kita bisa mengobservasi bagaimana perempuan dituntut sempurna dalam mengunggah foto wajahnya. Tidak boleh ada noda 
hitam, jerawat, bentuk wajah harus proporsional, pipi tidak boleh terlihat chubby. Penggambaran perempuan pada dunia media sosial pun mulai tidak sehat dan semakin menguatkan bahwa perempuan harus memberi sensasi dalam setiap apa yang ia unggah di akun miliknya. Tentunya ini sangat berpengaruh terhadap bagaimana interaksi bermedia yang dilakukan oleh perempuan melalui akun media sosialnya, terutama pada era digital ini. Di mana semua orang dapat mengakses bentuk aktualisasi dari setiap individu lainnya.

\section{Hasil}

\section{Prosedur umum}

Peneliti menggunakan metode analisis konten untuk menjawab pertanyaan penelitian. Analisis konten dilakukan pada portal berita online. Berita menjadi sampling yang diambil peneliti, sebab ukuran data yang bisa dikuantifikasi pada analisis konten dirasa lebih mudah dibandingkan jika harus mengambil sampel iklan atau sesuatu yang menggunakan kekuatan audio visual. Selain itu, konten berita memiliki elemen tulisan yang bisa ditafsirkan per kalimatnya tanpa harus melalui proses penyalinan teks terlebih dahulu. Untuk memudahkan proses penafsiran, peneliti membuat coding book atau protokol terkait proses pengkodingan artikel berita.

Analisis konten yang dilakukan berpacu pada teks berita yang membahas tentang kehidupan para aktor dan aktris. Definisi artis dalam penelitian ini, dibatasi oleh penulis hanya pada aktor dan aktris, yaitu laki-laki yang memerankan suatu pementasan skenario drama dalam panggung, radio, televisi, ataupun film. Pun sama halnya dengan aktris, yang mana perbedaannya hanya pada jenis kelamin di mana aktris ialah perempuan. Kajian utama yang menjadi bahan dasar penelitian ini adalah bagaimana portal berita tersebut menyajikan berita tentang aktor/aktris dilihat dari sisi gendernya. Tiga kategori hard content, soft content, dan equal content menjadi kategorisasi yang peneliti gunakan dalam analisis ini. Penjelasan dari kedua kategori tersebut akan dibahas pada bagiannya sendiri.

Untuk memulai analisis konten, dipilih 3 orang sebagai koder untuk mengklasifikasikan data yang telah dikumpulkan. Klasifikasi data dilakukan dengan menggunakan coding book yang telah dibuat sebelumnya. Koder lalu mengklasifikasikan data kepada 2 kategori, yaitu gender dan jenis konten. Para koder lalu memulai proses koding selama 2 jam. Setelah itu, diadakan diskusi oleh para koder terkait pengkategorian konten yang dilakukan sebelumnya hingga mencapai kesepakatan tentang klasifikasi data yang dilakukan. Setelah dilakukan proses koding, dilakukan proses analisis data. Mulai dari proses validitas dan reliabilitas hingga analisis deskripsi tabel perhitungan. Reliabilitas diukur melalui SPSS dengan memasukkan data dari hasil koding. Nilai dari Cohen's Kappa menjadi tolak ukur reliabilitas data yang telah di koding. Kemudian, analisis deskripsi tabel dilakukan dengan menghitung frekuensi konsep gender dan konten berdasarkan hard content dan soft content. Hasil dari perhitungan frekuensi ini nantinya digunakan untuk mengetahui kecenderungan hard content dan soft content pada portal berita di Indonesia. Terakhir, metode crosstabs digunakan untuk mengetahui hubungan antara konsep hard content-soft content dengan pemberitaan yang mempunyai kecenderungan memberitakan laki-laki atau kecenderungan memberitakan perempuan.

\section{Populasi dan Sampling}

Populasi yang digunakan adalah konten berita yang berasal dari portal-portal berita di Indonesia. Sampling yang digunakan adalah purposive sampling. Sampel diambil dari 3 portal berita yang menerbitkan artikel terkait aktor dan aktris. Portal berita tersebut adalah 
tribunnews.com, cnnindonesia.com, dan kompas.com. Artikel yang diambil dari tiga portal berita ini dimulai tanggal 14 Oktober 2019 hingga 14 November 2019. Tujuan dari dipilihnya purposive sampling adalah agar dapat terpilih data yang dapat menjelaskan keadaan yang terjadi saat ini. Total artikel yang dikoder ialah sebanyak 30 artikel, dengan rinciannya masing-masing dari tiga portal menyumbang 10 artikel.

\title{
Pembahasan
}

Kategori gender

Rater1 dan Rater2

Pada hasil perhitungan pertama antara rater 1 dan rater 2, didapatkan kesepakatan pengukuran Kappa dengan nilai 1.000. Hasil ini termasuk ke dalam kategori almost perfect dalam Cohen's Kappa.

Rater1 dan Rater3

Pada hasil perhitungan pertama antara rater 1 dan rater 3, didapatkan kesepakatan pengukuran dalam bentuk Kappa dengan nilai 1.000. Hasil ini termasuk ke dalam kategori almost perfect dalam Cohen's Kappa.

Rater2 dan Rater3

Pada hasil perhitungan pertama antara rater 2 dan rater 2, didapatkan kesepakatan pengukuran dalam bentuk Kappa dengan nilai 1.000. Hasil ini termasuk ke dalam kategori almost perfect dalam Cohen's Kappa.

\author{
Rata-Rata 1-2-3: \\ Mean Kappa $=1.000$
}

\section{Kategori konten}

Rater1 dan Rater2

Angka perhitungan reliabilitas Kappa antara rater 1 dan rater 2 pada kategori konten berita ialah sebesar 0.936. Pada kategori interpretasi perhitungan Kappa, 0.936 merupakan interval yang masuk pada kategori kesepakatan yang hampir sempur atau almost perfect agreement.

Rater1 dan Rater3

Angka perhitungan reliabilitas Kappa antara rater 1 dan rater 3 pada kategori konten berita ini ialah sebesar 0.876. Di mana menurut interpretasi Kappa, angka ini termasuk pada kategori almost perfect agreement.

Rater2 dan Rater3

Angka perhitungan pada rater 2 dan rater 3 dalam kategori konten berita ialah sebesar 0.815, di mana dalam interpretasi Kappa angka ini termasuk dalam kategori kesepakatan hampir sempurna atau almost perfect agreement.

\section{Rata-Rata 1-2-3:}

$$
\text { Mean Kappa }=0.876
$$

Pada berita-berita yang telah diambil secara purposive sampling tersebut didapatkan bahwa $50 \%$ berita merupakan berita yang meliput aktor laki-laki. Sisanya, 43,3\% merupakan pemberitaan aktris perempuan dalam tiga portal berita online dan 6,7\% tidak diketahui meliput aktor atau aktris menurut gender secara khusus. Secara lebih lanjut, sampel berita 
yang diambil dari portal berita Tribun dalam kurun waktu yang ditentukan membahas aktor $50 \%$ dan aktris pun $50 \%$. Tribun tidak meliput berita yang bebas gender dalam kurun waktu tersebut. Pada portal berita CNN, membahas 50\% aktor laki-laki. Dalam rentang waktu yang sama pun mereka hanya membahas aktris perempuan sebesar $30 \%$ dan sisanya meliput berita yang bebas gender. Sedangkan dari portal berita Kompas, 50\% membahas aktor laki-laki dan $50 \%$ membahas aktris perempuan.

Perihal konten yang diliput, terdapat 50\% konten yang tergolong soft content yaitu meliput mengenai fashion, kecantikan, kesehatan, edukasi, finansial personal, makanan, seni, literatur, dan hiburan. Sebanyak 36,7\% merupakan hard content yang berisikan bahasan berat mengenai bisnis, politik, olahraga, kriminalitas, dan teknologi. Sisanya yang secara khusus membahas secara adil mengenai soft dan hard content. Sampel berita yang didapatkan dari portal berita Tribun ditemukan ada $40 \%$ yang membahas mengenai hard content dan 50\% yang membahas tentang soft content, sementara $10 \%$ secara adil membahas keduanya. CNN dalam kurun waktu tersebut meliput berita hard content sebesar $70 \%$. Ini jauh dibandingkan berita soft content yang mereka liput yaitu hanya sebesar 30\%. Sedangkan Kompas, meliput berita hard content sebesar $40 \%$, soft content sebesar $30 \%$. Pada koder terjadi ketidaksepakatan perihal jenis konten yang diliput kompas yaitu pada sampel berita ke tujuh, delapan, dan sepuluh. Sehingga sebesar $20 \%$ berada pada argumen antara konten hard atau soft content dan sisanya berargumen antara berita soft atau equal content.

Pada uji Crosstabs antara variabel jenis gender pemberitaan dengan jenis konten berita tersebut, ditemukan hasil bahwa pada jenis pemberitaan mengenai aktor, 66,67\% merupakan berita hard content, $20 \%$ merupakan berita soft content dan sisanya tidak dapat terdeterminasi secara nyata. Pada pemberitaan mengenai aktris, 23,07\% merupakan berita hard content sedangkan $61,53 \%$ adalah berita soft content, dan sisanya merupakan equal content dan tidak dapat terdeterminasi. Sedangkan pada berita yang terkategori bebas gender $100 \%$ merupakan berita hard content. Dapat signifikansi yang dapat dilihat bahwa berita yang meliput mengenai aktor (laki-laki) didominasi berita hard content sedangkan pemberitaan aktris (perempuan) lebih mengacu pada soft content.

\section{Diskusi}

Berdasar hasil yang dimiliki peneliti dan rekannya terkait analisis konten pada 30 artikel portal berita online, didapatkan jawaban afirmatif dari pertanyaan penelitian. Konten berita soft didominasi pada berita dengan subjek perempuan sebesar 61,53\%. Pada bagian ini, peneliti ingin mencoba mengaitkan bagaimana standar kehidupan perempuan kemudian diciptakan oleh media ini. Soft content yang meliputi pemberitaan seputar; dunia fashion, kecantikan, edukasi, keuangan pribadi, makanan dan perjalanan, kesenian, serta hiburan; menjadi sebuah gambaran bahwa pasar telah diciptakan.

Bagaimanapun, menghadapi era industri digital kali ini, media tidak akan dapat berdiri sendiri, terutama dalam menciptakan konten. Institusi media turut memiliki tanggung jawab sosial terhadap para pemangku kepentingan dari konten mereka; Nurani individu, objek penilaian moral, pendukung finansial, kolega, masyarakat, dan juga institusi itu sendiri.

Pada kehidupan perempuan, hemat saya media mengkategorikan hard dan soft untuk menarik atensi masyarakat. Perempuan diberatkan dalam kategori soft, sehingga kesan yang 
diciptakan adalah memang kehidupan perempuan akan sebatas pada kecantikan, hiburan, dan hal-hal 'tidak genting' lainnya untuk diberitakan. Hal semacam ini pun memang diamini oleh masyarakat Indonesia. Segala hal yang genting dan mewakili kebutuhan orang banyak akan disematkan secara garis besar pada kehidupan laki-laki.

Semakin media menciptakan nilai tersebut, maka bisa saja semakin tidak ideal konten media yang tercipta. Disadari atau tidak, hal-hal yang dikaitkan dengan perempuan dalam media, sering kali merupakan ranah privasi yang dibawa ke ruang publik. Padahal, pada dasarnya negri ini mudah riuh terhadap permasalahan privasi yang kemudian dipublikasikan. Sebagai contoh kecil, ketika Agnes Monika tersandung permasalahan yang diangkat oleh para netizen Indoenesia. Pada saat itu, Agnes dianggap menyatakan secara implisit tidak mengakui Indonesia. Padahal yang dilakukannya adalah memberikan pernyataan bahwa memang ia tidak terlahir di Indonesia dan tidak memiliki darah (dalam artian sebenarnya) Indonesia. Hal semacam ini saja pada konten media, dapat kita lihat sebagai sebuah pemicu konflik dalam bermedia.

Dalam kasus lain pun, munculnya berbagai akun acne fighter seperti milik crvhons, nvnrsm, atau puspitamygsari misalnya, adalah hasil dari bentukan media dalam menciptakan standar perempuan dalam dunia Instagram. Ketiga akun ini bermaksud ingin mematahkan bahwa cantik pada Instagram haruslah melalui unggahan dengan tampilan wajah yang tanpa kekurangan atau flawless. Akun ini bermaksud memberikan persepsi baru, bahwa cantik dalam Instagram haruslah percaya diri pada wajah yang diunggahnya pada akun Instagramnya. Ini lah apa yang diciptakan oleh para pemilik akun media sosial mereka sendiri. Karena faktanya, dapat kita lihat secara langsung, akun-akun Instagram milik selebritis, terutama perempuan, sebagian besar unggahannya adalah berupa perwujudan wajah cantik mereka. Hal berbeda yang akan dilakukan mereka adalah saat mereka menggunggah gambar swafoto mereka dengan tanpa menggunakan polesan pada wajahnya. Ini berarti, dominasi teks yang sudah menguasai dunia Instagram adalah wajah tanpa kekurangan atau flawless tersebut.

Soft content yang tercipta, dapat dikatakan cukup berhasil dalam menciptakan pengambilan keputusan yang dilakukan para perempuan. Para influencer misalnya, mereka memiliki banyak pengikut yang nantinya akan terinspirasi berbagai kegiatannya dari influencer ini. Ketika influencer misalnya sedang membagikan rahasia bagaimana memiliki kulit wajah yang putih, dengan menyebutkan berbagai produk untuk digunakan, sedikit atau banyak dari pengikut mereka pun akan berpotensi melakukan hal yang sama seperti si influencer ini. Pada akhirnya, pengikut ini pun juga turut menggunakan atau membeli produk yang sama seperti yang digunakan influencer kebanggaannya ini.

Era revolusi industri 4.0 ini, menjadi saat yang tepat bagi media untuk mencari 'tempat' di hati masyarakat. Pasalnya, media sudah menciptakan sebuah industri di mana masyarakat mendatangi industri tersebut untuk memenuhi wacana dominan yang sudah dikembangkan media. Perkembangan teknologi yang sudah terkonvergensi bersamaan dengan akses media yang mulai pesat dirasakan masyarakat, menjadi modal utama dan terbesar untuk media mengembangkan pasar industri tersebut. Klasifikasi konten media ini lah menjadi salah satu manifestasinya.

Namun sayangnya, kedua klasifikasi tersebut bersifat dikotomi. Jika suatu konten bukan termasuk dalam kategori soft, maka berarti konten tersebut berkategori hard, begitupun sebaliknya. Kecenderungan perempuan berada di dalam soft content setidaknya menimbulkan pandangan bahwa apapun yang berada di perempuan, kemungkinan besarnya 'tidak terlalu penting'. Oleh karenanya, peneliti merasa seharusnya ada kategori penengah dalam konten media yang menjembatani antara soft dan hard content sehingga pandangan 
perempuan pun bisa digeser ke arah pertengahan ini. Seperti misalnya terdapat kategori general content atau equal content seperti yang peneliti masukkan ke dalam kategori penelitiannya.

Kategori penengah ini bisa saja berupa berita yang aktual, namun jika tidak diberitakan tidak ada sesuatu yang dirasa tertinggal, berita penting yang menyangkut kepentingan beberapa grup tertentu, fakta saintifik, penelitian, dan semacamnya. General content ini merupakan konten yang penting, tetapi tidak genting untuk dipublikasikan. Ini menjadi irisan antara kedua kategori dari soft dan hard. Tingkat kepentingan yang dimiliki sama dengan hard content dan tingkat tidak terikat waktunya sama dengan seperti soft content. General content ini lah yang menjadi irisan di antara keduanya. Karena pada faktanya, perempuan tidak melulu berbicara tentang dunia kecantikan, gossip, hiburan, seni, dan lainnya, tetapi juga perempuan banyak yang menaruh perhatiannya pada dunia ilmiah, pendidikan, ekonomi, atau bahkan politik sekalipun. Adanya pendekatan general content nantinya, berpotensi mengangkat ranah perempuan ke arah yang bisa dianggap lebih penting di dalam konten media.

\section{Simpulan}

Temuan peneliti menyatakan bahwa konten media dengan kategori soft content didominasi oleh subjek perempuan sebesar $61,53 \%$. Hal-hal yang diliput pada kategori ini antara lain; dunia fashion, kecantikan, edukasi, keuangan pribadi, makanan dan perjalanan, kesenian, serta hiburan. Maka dengan mengabaikan faktor lain, ceteris paribus, klasifikasi konten media mengacu pada gender. Laki-laki akan cenderung berada pada konten hard sedangkan perempuan akan cenderung berada pada konten yang soft. Mengingat budaya di Indonesia mengamini bahwa laki-laki memang lebih kuat daripada perempuan. Sehingga apabila kategori soft content disematkan kepada mayoritas perempuan pun, masyarakat akan permisif terhadap hal tersebut. Padahal, perempuan pun juga bisa lebih dari itu.

Sekiranya untuk mengurangi marginalisasi terhadap perempuan di media ini, peneliti mengusung adanya kategori general content sebagai kategori yang diakui dalam dunia praktik bermedia. Sayangnya, penelitian ini belum menganalisis lebih jauh bagaimana tingkat urgensi dari eksisnya general content ini sebagai usaha dari minimalisasi stereotipe yang media kerap lakukan terhadap perempuan. Penelitian ini masih kekurangan elemen komunikasi yang seharusnya juga diteliti, nyatanya elemen tersebut belum tercantum di dalam penelitian. Seperti misalnya elemen feedback komunikan terhadap konten media yang dinilai kerap memojokkan perempuan, atau elemen sifat saluran komunikasi itu sendiri (media cetak, online, sosial, dll). Untuk itu peneliti berharap adanya penelitian lebih lanjut untuk melengkapi elemen komunikasi yang masih kurang serta menjawab bahan diskusi terkait general content.

\section{Daftar Pustaka}

Basnyat, I., \& Chang, L. (2014). Are You a "Woman"? Representation of Femininity in Two Women's Magazines in Singapore, Cleo and Her World. Communication Research Reports, 31, 82-91.

Boczkowski, P. J. (2009). Rethinking Hard and Soft News Production: From Common Ground to Divergent Paths. Journal of Communication, 59, 98-116.

Day, A. L. (2006). Ethics in Media Communications . Louisiana: Thomson Wadsworth. 
Glogger, I., \& Otto, L. P. (2019). Journalistic Views on Hard and Soft News: CrossValidating a Popular Concept in a Factorial Survey. Journalism \& Mass Communication Quarterly, 96(3), 811-829.

Hadkinson, P. (2011). Media, Culture, and Society. London : SAGE.

Hartley, J. (1982). Understanding News . London : Routledge.

Johannsdottir, V. (2018). Commercialization in the Icelandic Press: An analysis of hard and soft news in major print and online media in Iceland in times of change. Journalism, 1-17.

Matthes, J. (2009). What's in a frame? a Content Analysis of Media Framing Studies in the World's Leading Communication Journals, 1990-2005. J\&MC Quarterly, 86(2), 349-367.

Perloff, R. M. (2014). The Dynamics of Political Communication: Media and Politics in a Digital Age. New York: Routledge.

Reinemenn, C., Stanyer, J., Scherr, S., \& Legnante, G. (2011). Hard and soft news: A review of concepts, operationalizations and key findings. Journalism, 13(2), $221-239$.

Rios, M. E., Rodgers, S., Thorson, E., \& Yoon, D. (2005). Representation of Women in News and Photos: Comparing Content to Perceptions. Journal of Communication, 152-166.

Siregar, H. (1999). Menuju Dunia Baru: Komunikasi, Media, dan Gender. Jakarta : YakomaPGI.

Vandenbosch, L., \& Eggermont, S. (2013). Sexualization of Adolescent Boys: Media Exposure and Boys' Internalization of Appearance Ideals, Self-Objectification, and Body Surveillance. Men and Masculinities, 16(3), 283-306.

Willzig, S. N., \& Seletzky, M. (2010). Hard news, soft news, 'general' news: The necessity and utility of an intermediate classification. Journalism, 11(1), 37-56.

Yang, F.-c. I. (2007). Beautiful-and-Bad Woman: Media Feminism and the Politics of Its Construction. Feminist Studies, 33(2), 361-383. 